\title{
Widening Access of Nigerians to Distance Education Programmes
}

\author{
Cecilia A. Beshela ${ }^{*}$, Glory, B. Asuquo a, Violet O. Ekpenyonga \\ a Department of Continuing Education and Development Studies, Faculty of Education, University of Calabar, Calabar, Nigeria. \\ *Corresponding author's email address: beshelakpana@gmail.com
}

\section{A R T I C L E I N F O}

Received: 15-06-2017

Accepted: 07-07-2017

Available online: 31-07-2017

\section{Keywords:}

Correspondence school, learning and teaching;

Distance education programmes;

Widening access.

\begin{abstract}
A B S T R A C T
Two distance education programmes prominently exist in Nigeria. These are the Nigerian Certificate of Education (NCE) distance learning programme and the Open University distance education models. Ample evidence abounds to show that numerous Nigerians have not maximally taken advantage of these programmes to acquire requisite knowledge and skills in order to fit into the world of work and/or to improve their productivity. A plethora of factors underlie these unsavory situations. This paper highlights the inherent needs to the participation of Nigerians into these distance learning programmes and also suggests different strategies for widening or enhancing the access of more Nigerians to these new paradigms of accessing education.
\end{abstract}

JEL Classification:

A20, I22

(C) 2017 The Authors. This is an open access article under the terms of the Creative Commons Attribution License 4.0, which allows use, distribution and reproduction in any medium, provided the original work is properly cited.

DOI: http://dx.doi.org/10.18533/rss.v2i7.105

ISSN 2378-8569(Print), ISSN 2378-8550(Online)

\section{Introduction}

Distance Education has been in existence for centuries and has people at one point or the other. It involves acquiring knowledge outside the traditional avenues of attendance at learned institutions. Mugridge (1992) sees distance education as; "a form of education in which there is normally a separation between the teacher and learner and thus one in which other means-the printed and written words, the telephone, computer conferencing for example-are used to bridge the physical gap".

Nikky (2010) sees distance education as a modern system of non-formal education. It is imparted through correspondence or postal courses, contact, electronic media like radio, television, video and audio cassettes, and other audio-visual aids. Other terms used for distance education as presented by Nikky (2010) Dokubu (2013) and Cafarrella (1993) include;
a) Distance learning
b) Distance teaching
c) Open education
d) Open learning
e) Open school
f) Open university
g) University of air
h) University without walls
i) Tele university
j) Out of school education 
k) Correspondence learning

l) Correspondence teaching

m) Correspondence school

Whatever term used, it implies the method of learning at ones' own pace and time without the boundaries of the formal classroom and without the formal presence of the teacher.

Distance education opens more opportunities for people to learn and it provides whatever educational opportunities that are needed by anyone, anywhere and at any time as it does not necessarily require a face-toface contact. This is why the target groups needs distance education since it creates more open and wider access to education.

Peters (2016) says that there is more to distance education than what the popular believe holds. He maintained that while thinking or discussing distance education, we should bear in mind the roles it plays in the lives of the different target and disadvantaged groups which he refers to as, the true nature of distance education which include;

- The special humanitarian goal - the education of the neglected and underserved, among them, minority people.

- To the extension of university education to adults and persons with vocational and family obligations, to the goals of realizing lifelong learning, to a university which is open to all people who are able to study and are offered "a second chance" for enjoying and profiting from higher education.

- To the unparalled opportunities for scientific continuing education so badly needed in our age of constant technological, societal and cultural change.

- To its contribution to university reforms which must be modernized and,

- To its function as forerunner of the coming tele-learning and the "virtual university."

He sees distance learning or education as not just campus based learning with the help of particular technical media, but as an entirely different approach, with different students, objectives, methods, media, strategies, and above all, different goals in educational policy. These different approaches, methods, models and strategies are so planned to take care of, and accommodate the different learning needs of the participants who are mostly these target groups at any point in time. Meaning that, with the different methods and techniques through these modern media the target groups have access to education even while they are in their different places of engagement such as in the farms, markets, stores, shops, while grazing, fishing, caving or even in their homes for those in pudah. Holton, Swanson and Naquin (2001) see distance education as one means of achieving wider access to learning as people learn through their phones, ipads, computers and other print and electronic media easily and at any time and place distance education increases to educational opportunities for the wider segment of the population even to the remote areas of the society and accommodating the different situations and educational needs of these target groups.

Perhaps that is why the definition of UNESCO (1975) cited in Sarumi (2001) is best suited for this paper, for it describes distance education or open learning as; such systems that are designed to offer opportunities for part time study, for learning at a distant and innovations in the curriculum. They are intended to allow access to wider sections of Adult population, to enable students to compensate for lost opportunities in the past or to acquire new skills and qualifications for the future. It arms to readdress social or educational inequality and offer opportunities not provided by conventional colleges or universities. In this system, restrictions on learning are fewer than those of formal educational institutions.

This definition spells out the fact that distance education allows wider access to the wider sections of the adult population to compensate for lost opportunities and aims at redressing social and educational inequalities. Here, we see a chance for these target groups to grab and make use of, to fill-in-the gap of educational inequality with others who want to acquire education through conventional institutions. It is a fact also that even though some children and youths made up the population of the target, marginalized, unreached, or disadvantage groups, majority of them are full-blown adults who need more access to education to enable them become more informed and to attain to other societal issues.

\section{2. $\quad$ Reasons for distance education}

Distance education has over the years serve the needs of a larger clientele and have continue to make appeals for most people in the developed world as it provides wider access to education for various categories of people. Distance education, therefore, has proven to be almost the best form of Adult Education in providing wider access to education for different categories of people even in Nigeria. The following points therefore, highlight the need and importance of distance education to the education of Nigerians as presented by Nikky (2010), Peters (2016) and Holton et'al (2001).

a) Easy Access - The programme provides easy access and opportunities to a large group of people who had previously been denied such opportunities to achieve their educational goals, or make up for the time lost in acquiring education. This can help them improve their educational qualifications and brighten up their chances of promotions and self-improvement. 
b) Democratic Aspiration - It is needed to meet the great demand for democratization of education for those marginalized, disadvantaged, target groups, and the unreached or those neglected in the society.

c) It is needed to achieve universal education in order to achieve the cherished goal of "Education for All" (EFA).

d) It is needed to provide self-improvement for those otherwise deprived of receiving proper education through self-learning.

e) It is important and needed because it can be used to teach people of different ages (it serves both Peadagogical and Androgogical purposes and clientele) and it also teach course from a wide range of disciplines as noted by Nikky (2010).

f) It is important because it serves those who may be socially isolated or who are disadvantaged due to financial, physical, emotional or family background or even those who are geographically isolated due to distance.

g) It is needed to serve those who have the desire to improve upon their qualification while on the job. It provides ample opportunities for such people to improve their qualification.

h) It is also needed because it encourages learning and earning for different categories of workers, as it satisfies their varied needs for educational pursuit.

i) It is important because there is explosion of knowledge as a result of rapid scientific and technological developments which the formal school system cannot speedily provide as desired, as a result of its rigidity and high cost.

\section{Selected models of distance education to serve educational needs of most Nigerians}

There are several models of distance education in the field of study but a few selected ones that are deemed meaningful for the topic at hand are presented here to suit the purpose as presented by Peter's (2016) and Sarumi (2001). The models include;

- the examination preparation model

- the correspondence education model

- $\quad$ the multiple (mass) media model

- the groups distance education model

- $\quad$ the network-based distance teaching model

- $\quad$ the technologically extended classroom model

These models as presented by Peters (2016) are to provide more information on the fundamental ideas behind distance education that makes it distinct from other programmes of Adult Education in providing wider access to education for the disadvantaged, marginalized, target groups and the unreached. Lets briefly look at the application of these models;

The examination preparation model: Even though not discussed in the literature of distant learning, Peters (2016) believes that it is being applied and it plays a certain role in distance education both in history and in current situations mostly in this $21^{\text {st }}$ century. In this model, the students teach themselves, while the University limits itself to holding examinations and conferring degrees on the students but without actually engaging in the teaching. He stated that the model was institutionalized in the middle of $19^{\text {th }}$ century by the University of London to benefit those person who could not afford to be enrolled at the Oxford University. The University supported the distance education students only by informing them about the examinations and the rules and regulations governing examination as well as providing some reading text to aid them. Presently, as he reported, the model is being practised by the Regents of the University of New York.

Nigeria can also borrow and apply this model to encourage the target groups to obtain degrees at their convenience. It is a form of independent or autonomous learning and most people who have no time to go through the conventional Universities can make use of this opportunity. If it has worked successfully in other parts of the world, it will also work here in Nigeria and many will key into, and benefit from it.

\section{4. $\quad$ The corresponding education model}

This is the oldest form or model of distance education. It combines examination model in addition to regular teaching through printed and written teaching text. It goes with assignments and has a regular and adhoc correspondence between the students and the institutions. It is simple and cost-effective as the teaching text can be mass produced by the printing press to serve the needs of the students as pointed out by Dokubu (2013). Though very old, this model is still used extensively in this $21^{\text {st }}$ century and inspite of the modern worldwide interest in the digitalization of information and education, this model is still been preferred by some universities like the university of South Africa, English correspondence colleges, French Ecoe Universelle as pointed out by Peters (2016) and Sarumi (2001).

The next model of interest here is the network-based distance education model: This model provides for the possibility to work in a digitalized learning environment where students have access to even the remotest teaching programmes and data based with relevant information. It provides the most convenient learning 
situation. The students may use CD-ROMs with distance education course in hypertext-form or use the simple data bases while studying a course. Students can learn from their homes using their computers, internet materials, phones and other digitalized gadgets. It also combines other models like "the technologically extended classroom teaching model" where one teacher teaches a college class or a studio class via the internet and his presentation or instructions is transmitted to two or more other classes by a cable satellite TV or with the help of a video conference system. It is currently been used in the U.S.A as pointed out by Peters (2016) and Nikky (2010) and this is to provide wider access to education for those who cannot attain the regular school system. This model is most encouraging in providing wider access to education for the target groups in Nigeria as it can conveniently meet the needs of the students even in their villages, farms, markets or work places with ease. It helps them not only to learn educational content curriculum prepared, but also to become computer literate with the constant use of the computer, internet, phones applications etc. This will help them to be in-tune with the global world.

The other models not explained in details such as 'the autonomous learner model, the multiple (mass) media model and the group distance education models' are deliberately skipped because they are interwoven into those discussed here.

\section{Strategies of distance education in attaining to the learning needs of most Nigerians}

The strategies implied here are those as presented by Makeachie Pintrich, Lin and Smith (1986) popularly referred to as taxonomy of learning strategies. These learning strategies by the above authors flow as follows:

i) Cognitive strategies

- Rehearsal strategies

- Elaboration strategies

- Organizational strategies

ii) Metacognitive strategies

- Planning strategies

- Monitoring strategies

- Regulating strategies

iii) Resource management strategies

- Time management

- Study environment

- Effort management

- Support of others

\section{i) Cognitive strategies}

It focuses on methods by which students actively process information and store this information into memory. It has three stages namely:

- Rehearsal strategies used by students to recall materials using repetition by either repeating the material aloud, copying the material, taking selective verbatim notes and underling the most important parts of the materials.

- Elaboration strategies are the process by which students build an internal connection between what is being learned and previous knowledge. Specific tactics include paraphrasing, summarizing, creating analogies, and question and answering. These are ways of elaboration which learners can use with ease.

- Organizational strategies are the process by which leaners gather together and build connections with the information received in the learning environment. By gathering together and contributing, discussing and organizing their own ideas into concrete concepts, they learn faster. Tactics used include selecting main ideas through outlining, networking and diagramming the information.

ii)

\section{Metacognitive strategies}

It focuses on skills used by students to plan their strategies for learning, to monitor their present learning and to estimate their knowledge in a variety of domains. The metacognitive strategies improve selfregulation by encouraging students to test their understanding and to detect problems areas. It has three stages namely;

- Planning - this is done through setting goals, skimming the material and generating questions.

- Monitoring involves the process by which the students check themselves for comprehension of knowledge or skills. It enhances improved acquisition, generalization and transfer of knowledge from one area to another. 
- Regulating: This entails the process of adjusting reading rate, reviewing or using test-taking tactics.

\section{iii) Resources management strategies}

This is concerned with the quality and quantity of the task involvement. There are four stages namely;

- $\quad$ Resource (time) management - the process of developing well-defined goals and assigning time to the course to obtain the best results.

- Study environment - this is the development of a conducive setting for learning to take place. The learning environment selected must be defined, quiet and organized for learning with chairs and tables for the students.

- Effort management is the process by which learner is able to use tactics such as attribution to effort, mood, self-talk, motivation persistence and self-reinforcement.

- Support of others - students must learn to utilize this by seeking help from other students and the instruction.

Friedman and Fisher's (1998) identified strategy categories and 14 instructional strategies. The strategy categories are;

i. Process strategies to enhance students' learning and adaptation

ii. Teaching strategies to increase students' learning and;

iii. Strategies to manage the classroom by use of appropriate time dimension

The fourteen instructional strategies are - achieved through:

a) Providing reminders strategy as cue to recall of information required to perform assigned tasks. Reminders like mnemonic devices, highlighted words etc.

b) Providing transfer of learning instruction - here, learning objectives achievement is enhanced when students are taught beforehand the knowledge and skills needed to perform assigned tasks and how to determine when learned knowledge and skills can be used to perform task.

c) Providing teamwork instruction strategy - student are taught to perform complementary tasks as a team in pursuit of the objective through study groups, discussion, continual collaborative feedback etc.

Teaching strategies are achieved through:

d) Taking student readiness into account

e) Defining instructional expectation

f) Providing effective evaluation and remediation given after feedback on effective evaluation is given to students without delay.

g) Providing contiguity by ensuring that events students are to associate are presented to them close together in time and space.

h) Utilizing repetition effectively in instruction and tasks assigned to students to perform.

i) Clarifying communication through proper passage of information on objectives, tasks and evaluation to students.

j) Reducing student/teacher ratio in teaching situation

k) Providing subject matter unifier through the use of scheme of work to highlight parts or whole relationships in the subject matter.

Strategies to management of classroom are achieved through:

l) Providing ample learning time - considering the nature of the students and the environment as well as the peculiarities of their learning needs.

m) Keeping students on task - either by take home assignments, group assignments, fieldwork exercise etc.

\section{Approaches for distance education students} these are:

Morgan (1991) identified two approaches through which distant students' develop as learners and

Surface Approach;

- Focus on the signs (e.g the text or instruction itself)

- Focus on discrete elements

- Memorize information and procedures for tests

- Unreflectively associate concepts and facts

- Fail to distinguish principles from evidence, new information from old

- Treat assignments as something imposed by the instructor

- External emphasis focusing on the demands of assignments and examination leading to a knowledge that is cut off from everyday reality. 
Deep approach:

- Focus on what is signified (e.g the instructor's arguments)

- Relate and distinguish new ideas and previous knowledge

- Relate concepts to everyday experience

- Relate and distinguish evidence and argument

- Organize and structure content

- Internal emphasis focusing on how instructional materials relates to everyday reality.

From the above it is advised that one, two or a combination of these strategies be employed and used by the providers of distance education (facilitators) will go a long way to helping the learners to achieve their objectives and purpose of wanting to learn.

\section{Conclusion}

Providing wider access to education for the adults and target groups in our society should be taken seriously in this our current time of constant change. Distance education is seen here as 'the university of the future' and should be bore in mind while planning for development for a brighter future for our society.

The target groups, adult men and women, disadvantaged group, marginalized groups or the unreached needs wider access to education in order to better their lives, improve their skills and efficiency, read and write and ability to communicate effectively with others and also to attain to other societal issues and responsibilities. It is therefore hoped that distance education be revitalized in it true form and publicized by the government, agencies for adult and non-formal education and ministries of education at the state levels, and the targeted groups be encouraged to imbibe it as a method or avenue of gaining more access to educating themselves and satisfying their educational goals.

\section{References}

Caffarella, R. S. (1993). Self-directed learning. retrieve from www.onlinelibrary.widey. Com. 23 ${ }^{\text {rd }}$ November, 2016.

Dokubo, C. (2013). Open and distance learning programme. Obio-Akpo: Chronnett Press, DC Int'I Royal Academy.

Elwood, F., Holton, Richard A. Swanson, Sharon S. Naquin (2010: March). Andragogy in Practice: clarifying the Andrangogical model of Adult learning.

Fasokun, T., Katahoire, A. and Oduaran, A. (2005). The Psychological of Adult Learning in Africa. South Africa: UNESCO Institute for Education and Pearson Publishers.

Federal Government of Nigeria, (2008). National Blue Print for Adult and Non-Formal Education in Nigeria.

Friedman, S. P. and Fishers, I. (1998). Handbook on effective instructional strategies: evidence for decisionmaking. Institute for evidence-based decision-making in education, Inc. Columbia, SC.

Holton, E. F., Swanson, R. A. and Naguin, S. S. (2001). Androgogy in practice: clarifying the Androgogical model of learning.

Mckeachie, W. J., Pintrich, P. R., Lin, V. and Smith, D. (1986). Teaching and learning in the college classroom: A review of the research literature. Ann Arbor, M. I: National centre for Research to Improve Postsecondary Teaching and Learning University of Michigan.

Morgan, A. (1991). Research into student learning in distance education. Victoria, Australia: University of South Australia, Underdale (ED 342-371).

Mugridge, I. (1992). Distance education in single and dual mode Universities. Vancouver: The Communicate of learning.

Nikky, I. (2010:21 st July). Distance learning-concept of distance learning. Retrieved from www.indiastudychannel.com.

Onlinelibrary.ordey.com. 20 ${ }^{\text {th }}$ November, 2016.

Peters, O. (2016: 23 ${ }^{\text {rd }}$ Nov. 2016). Concepts and models of open and distance learning. Retrieved from www.uniodenburg.com 23 ${ }^{\text {rd }}$ November 2016. 